\title{
Records of myxomycetes from Maine
}

\section{Zoll $\mathbf{V}^{1}$ and Stephenson SL ${ }^{2}$}

${ }^{1} 5053$ Valley Stream Lane, Macungie, Pennsylvania 18062, zollvande@yahoo.com
${ }^{2}$ Department of Biological Sciences, University of Arkansas, Fayetteville, Arkansas 72701, slsteph@uark.edu

Zoll V, Stephenson SL 2015 - Records of myxomycetes from Maine. Mycosphere 6(5), 568-584, Doi 10.5943/mycosphere/6/5/6

\begin{abstract}
Historical records indicate that myxomycetes (plasmodial slime molds or myxogastrids) have been collected in Maine since the 1850's, with the efforts of Francis LeRoy Harvey during the last decade of the $19^{\text {th }}$ century being of particular importance. A review of myxomycete collections cited in the literature and available data from herbarium records yielded a total of at least 166 species representing 42 genera reported from or known to occur in Maine. Although many records (especially early ones) were incomplete with respect to the exact locality where they were collected, the three counties with the highest numbers of collections are Hancock, Penobscot and Washington. This undoubtedly reflects, as least in part, the presence of Acadia National Park in Hancock County, the University of Maine in Penobscot County, and the Eagle Hill Institute in Washington County.
\end{abstract}

Key words - boreal forests - Francis LeRoy Harvey - slime molds - taxonomy

\section{Introduction}

The myxomycetes (plasmodial slime molds or myxogastrids) are a group of fungus-like microorganisms common to sometimes abundant in terrestrial ecosystems (Martin \& Alexopoulos 1969). Myxomycetes are particularly common in forests, where their fruiting bodies are found in association with such microhabitats as coarse woody debris and the litter layer on the forest floor. When conditions are favorable (usually late spring through early fall in temperate regions of the Northern Hemisphere), it is possible to collect fruiting bodies that have developed under natural conditions in the field. However, the moist chamber culture technique as it applies to myxomycetes (Gilbert \& Martin 1933) also provides a convenient and often very productive method of supplementing field collections (Stephenson 1989, Rojas \& Stephenson 2013, Rollins \& Stephenson 2013, Wrigley de Basanta et al. 2013).

Historical records show that myxomycetes have been collected in Maine since the 1850's. The most important early collector was Francis LeRoy Harvey (1850-1900), who published a series of papers (Harvey 1896, 1897, 1899) reporting records from the state. During the period from 1876 to 1885 , Harvey was a member of the faculty at Arkansas Industrial University, which later became the University of Arkansas. At the time his first publication on the myxomycetes appeared in 1896, he had moved to Maine State College (also known as Maine State College of Agricultural and Mechanical Arts), which later became the University of Maine. Other noteworthy early collectors in Maine were Roland Thaxter, Andrew P. Morgan, and Elmer D. Merrill. Collectors in the 20th century included Robert L. Hagelstein, George W. Martin and an amateur mycologist with the last 
name of Eddy. The largest series of more recent collections were made by participants in the Eagle Hill seminars led by the second author and recorded from Acadia National Park by the first author.

Interestingly, for two species of myxomycetes, the type specimen was collected in Maine. The first of these is Dianema harveyi Rex, described by George A. Rex (1891) from a specimen collected in Orono and named for Harvey. The second species is Hemitrichia leiocarpa (Cooke) Lister (= Hemiarcyria leiocarpa Cooke), described by Cooke (1877) from a specimen collected in Portland by the Rev. E. C. Bolles. Both D. harveyi and H. leiocarpa have since been reported from a number of other localities throughout the world.

The present paper represents an effort to bring together as much information as possible related to the species of myxomycetes reported from or known to occur in Maine. This involved reviewing all records of myxomycetes cited in the literature as well as all available data from herbarium records, especially those of the National Fungus Collections (BPI) in Beltsville, Maryland), the University of Arkansas (UARK), the University of Florida Herbarium (FLAS), the Farlow Herbarium (FH) and the Royal Ontario Museum Fungarium (TRTC) as well as the database (http://slimemold.uark.edu) compiled by the University of Arkansas.

\section{General Study Area}

The state of Maine, located in the northeast corner of the United States, has a total land area of approximately $91,646 \mathrm{~km}^{2}$ (35,385 square miles), more than $80 \%$ of which is forested. In fact, Maine is one of the most heavily forested states in the United States. Most of the remaining area of the state is either agricultural or urban. The forests of Maine occur in a transitional zone between the Canadian boreal forests, consisting mostly of spruce (mostly Picea rubens Sarg.) and fir (Abies balsamea [L.] Mill.), and the mixed hardwood forests of the northeastern United States. The latter forests consist largely of broadleaf trees, although there also are some conifers. Three major forest regions have been described for Maine. These are (1) the forests of the northern portion of the state that consist of the spruce/fir forest type mixed with northern hardwoods, (2) mixed northern hardwood forests of the central part of the state, which are dominated by maple (Acer rubrum $\mathrm{L}$. and A. saccharum Marsh.), beech (Fagus grandifolia Ehrh.) and birch (Betula papyrifera Marsh. and $B$. alleghaniensis Britton); and (3) oak-pine forests of southern Maine that contain red oak (Quercus rubra L.), eastern white pine (Pinus strobus L.), red maple (Acer rubrum L.), white ash (Fraxinus americana L.), and several species of hickory (Carya spp.).

The forests of the northern portion of the state are located on granite parent material that extends from the White Mountains toward Mt. Katahdin in north central Maine and on well-drained soils derived from glacial till deposited during the last Ice Age. Mixed northern hardwood forests are found on the finer clay soils, while the oaks, white pine, ashes, and hickory grow on the sandy gravels. Maine's wet coastal areas and upland wetlands contain tamarack (Larix laricina [Du Roi] K. Koch), northern white cedar (Thuja occidentalis L.), and black spruce (Picea mariana [Mill.] Britton) to the north, with Atlantic white-cedar (Chamaecyparis thyoides [L.] Britton, Sterns \& Poggenb.), ash, hemlock (Tsuga canadensis [L.] Carrière), and black spruce to the south. These areas are developed from poorly drained organic soils with a heavy clay pan (McWilliams et al. 2003, McCaskill et al. 2011).

The forests of Maine have gone through several cycles of clearing and regeneration, including timber cutting, clearing for farmland, farmland abandonment and spruce budworm infestations. There are several areas of old-growth forest containing trees up to 200 years old, with some of these areas very small and others more than 12 ha $(50$ acres $)$ in total extent. The majority of the forests in Maine today are considered as productive timberland, also called industrial forests, but large areas of forests are in protected national and state parks (McCaskill et al. 2011).

\section{Results}

Based on the information compiled during the present study, at least 166 species in 42 genera have been reported as occurring in Maine. Some records were represented by specimens identified only to genus, so it is possible that the actual number is slightly higher. Arcyria cinerea, with 42 
herbarium records in UARK, would seem to be the most commonly encountered species, and field observations by the two authors suggest that the species is even more common than these records indicate. Lycogala epidendrum was represented by the second highest number of records, followed by Physarum viride. Although many of the historical records were incomplete as to location, the highest number of collections with location information were made in Hancock, Penobscot and Washington counties. This undoubtedly reflects, as least in part, the presence of the University of Maine in Penobscot County, the Eagle Hill Institute in Washington County and Acadia National Park in Hancock County.

\section{List of Species}

In the list that follows, myxomycetes are listed alphabetically, first by genus and then by species. Nomenclature essentially follows Lado (2001-2015).

Amaurochaete atra (Alb. \& Schwein.) Rostaf.

First reported by Harvey (1896) as Reticularia atra Fr. and based on a specimen collected by C. B. Fuller.

Arcyodes incarnata (Alb. \& Schwein.) O. F. Cook

First reported by Harvey (1897) as Lachnobolus incarnatus (Alb. \& Schwein.) J. Schröt. Harvey suggested that the material he had collected differed from what had been reported from Europe and possibly represented "a distinct American species, deserving a new name."

Arcyria cinerea (Bull.) Pers.

First reported by Harvey (1896), based on specimens collected by F. L. Harvey and G. Rex, and also listed in Harvey (1897). The most recent report was by Zoll and Stephenson (2013).

Arcyria denudata (L.) Wettst.

First reported by Harvey (1896) as A. minor Schwein., based on a specimen collected in 1895, and also as A. punicea Pers., based on specimens collected by F. L. Harvey and G. Rex. The species was listed again by Harvey (1899). The most recent report was by Zoll and Stephenson (2013).

\section{Arcyria ferruginea Saut.}

First reported by Harvey (1896) as A. aurantiaca Raunk., based on a specimen collected in 1892, and also as A. ferruginea, based on a specimen collected in 1893. The species was also listed by Harvey (1897) as Heterotrichia gabriellae Massee, based on a specimen collected by E. D. Merrill in 1896.

Arcyria helvetica (Meyl.) H. Neubert, Nowotny \& K. Baumann

Not reported in print as occurring the state but represented by a specimen collected by S. L. Stephenson in 2006 and deposited in UARK.

Arcyria incarnata (Pers. ex J.F. Gmel.) Pers.

First reported by Harvey (1896) as A. adnata Batsch, based on specimens collected by F. L. Harvey, the Rev. J. Blake and G. Rex, and also listed by Zoll and Stephenson (2013).

Arcyria insignis Kalchbr. \& Cooke

Not reported in print as occurring in the state but represented by a specimen collected by C. L. Shear in 1920 and deposited in BPI.

\section{Arcyria obvelata (Oeder) Onsberg}

First reported by Harvey (1896) as A. nutans (Bull.) Grev. and also listed by Zoll and Stephenson (2013). 
Arcyria occidentalis (T. Macbr.) G. Lister

This species was described as Lachnobolus occidentalis T. Macbr., by Macbride (1899), apparently based on specimens collected in Maine, Iowa, Missouri and Nebraska. Hagelstein (1944) listed the type locality as Maine, but Martin and Alexopoulos (1969) listed it as Iowa. Otherwise, the species was reported from the state by Ricker (1902) as L. occidentalis, based on a specimen collected by F. L. Harvey in 1898 .

Arcyria oerstedii Rostaf.

First reported by Harvey (1896), based on a specimen collected by G. Rex.

Arcyria pomiformis (Leers) Rostaf.

First reported by Harvey (1897), based on a specimen collected in 1890, and also listed by Zoll and Stephenson (2013).

Arcyria stipata (Schwein.) Lister

First reported by Harvey (1896) as Hemiarcyria stipata Schwein. and based on specimens collected in 1890 and 1895.

Badhamia capsulifera (Bull.) Berk.

First reported by Harvey (1896) as B. hyalina (Pers.) Berk., based on a specimen collected by the Rev. J. Blake, and also listed by Harvey (1897), based on a specimen collected by O. W. Knight in 1896.

Badhamia lilacina (Fr.) Rostaf.

Not reported in print as occurring in the state but represented by a specimen listed as being collected by F. Thaxter (but probably referring to R. Thaxter) and deposited in TRTC.

\section{Badhamia macrocarpa (Ces.) Rostaf.}

First reported by Harvey (1896).

Badhamia papaveracea Berk. \& Ravenel

First reported by Cooke (1877), based on a specimen collected by C. B. Fuller.

Badhamia utricularis (Bull.) Berk.

First reported by Cooke (1877), based on a specimen collected by C. B. Fuller, and also listed for the state by Harvey (1896).

Ceratiomyxa fruticulosa (O.F. Müll.) T. Macbr.

First reported by Harvey (1896) as C. mucida J. Schröt., and also listed by Harvey (1899) as C. mucida. The most recent report was by Zoll and Stephenson (2013).

Clastoderma debaryanum A. Blytt

First reported by Harvey (1897).

Clastoderma pachypus Nann.-Bremek.

First reported by Zoll and Stephenson (2013).

Collaria arcyrionema (Rostaf.) Nann.-Bremek. ex Lado

First reported by Harvey (1899) as Lamproderma arcyrionema Rostaf., based on a specimen collected in 1897, and also listed by Zoll and Stephenson (2013). 
Collaria lurida (Lister) Nann.-Bremek.

First reported by Zoll and Stephenson (2013).

Comatricha elegans (Racib.) G. Lister

First reported by Zoll and Stephenson (2013).

Comatricha cf. laxa Rostaf.

First reported by Zoll and Stephenson (2013).

Comatricha nigra (Pers. ex J.F. Gmel.) J. Schröt.

First reported by Sprague (1859) as Stemonitis ovata Pers. and based on a specimen collected by E. S. Morse. This appears to be one of the first records of any myxomycete from the state. Later, this species was reported by Cooke (1877) as $C$. friesiana de Bary and by Harvey (1896) as $C$. obtusata Preuss., based on specimens collected by G. Rex and B. Harvey. The most recent report was by Zoll and Stephenson (2013).

Comatricha pulchella (C. Bab.) Rostaf.

First reported by Zoll and Stephenson (2013).

Comatricha suksdorfii Ellis \& Everh.

First reported by Ricker (1902), based on a specimen collected by E. D. Merrill in 1896.

Craterium leucocephalum (Pers. ex J.F. Gmel.) Ditmar

First reported by Harvey (1896), based on a specimen collected by G. Rex.

Craterium minutum (Leers) Fr.

First reported by Harvey (1897), based on specimens collected in 1896 by F. L. Harvey and E.

D. Merrill, and also listed by Zoll and Stephenson (2013).

Craterium obovatum Peck

First reported by Harvey (1897) as Scyphium rubiginosum Chev., based on specimens collected by F. L. Harvey in 1895 and E. D. Merrill in 1896.

Cribraria argillacea (Pers. ex J.F. Gmel.) Pers.

First reported by Harvey (1899), based on a specimen collected by E. D. Merrill in 1897, and also listed by Zoll and Stephenson (2013).

Cribraria aurantiaca Schrad.

First reported by Harvey (1899).

Cribraria cancellata (Batsch) Nann.-Bremek.

First reported by Harvey (1896) as Dictydium umbilicatum Schrad., based on a specimen collected by G. Rex and identified initially as D. cernuum Pers. Somewhat later the species was listed by Ricker (1902) as D. cernuum Pers., based on a specimen collected by E. D. Merrill in 1897. The most recent report was by Zoll and Stephenson (2013).

Cribraria intricata Schrad.

First reported by Harvey (1896), based on a specimen collected by G. Rex, and also listed by Zoll and Stephenson (2013).

Cribraria languescens Rex

First reported by Zoll and Stephenson (2013). 
Cribraria macrocarpa Schrad.

First reported by Zoll and Stephenson (2013).

Cribraria microcarpa (Schrad.) Pers.

First reported by Zoll and Stephenson (2013).

Cribraria mirabilis (Rostaf.) Massee

First reported by Zoll and Stephenson (2013).

Cribraria oregana H.C. Gilbert

First reported by Zoll and Stephenson (2013).

\section{Cribraria purpurea Schrad.}

First reported by Harvey (1896) and also listed by Ricker (1902), based on a specimen collected by E. D. Merrill in 1897.

Cribraria cf. rufa (Roth) Rostaf.

First reported by Zoll and Stephenson (2013).

Cribraria splendens (Schrad.) Pers.

Not reported in print as occurring in the state but represented by a specimen listed as Dictydium splendens Schrad., collected by Eddy in 1917 and deposited in BPI.

\section{Cribraria tenella Schrad.}

First reported by Harvey (1896), based on a specimen collected by G. Rex.

\section{Diachea leucopodia (Bull.) Rostaf.}

First reported by Harvey (1896) as D. elegans (Trentep.) Fr., based on specimens collected by C. B. Fuller and G. Rex. In addition, the species was reported again by Harvey (1899) as $D$. elegans, based on a specimen collected in 1897, and also by Ricker (1902), based on a specimen collected in 1897 by E. D. Merrill.

\section{Diachea thomasii Rex}

First reported by Ricker (1902) based on a specimen collected by R. Thaxter in 1895 .

Diacheopsis cf. insessa (G. Lister) Ing

First reported by Zoll and Stephenson (2013).

\section{Dianema harveyi Rex}

First collected in 1889 and described as a species new to science by Rex (1891).

\section{Diderma cinereum Morgan}

First reported by Zoll and Stephenson (2013).

\section{Diderma effusum (Schwein.) Morgan}

First reported by Harvey (1899) as Chondrioderma reticulatum Rostaf. and based on a specimen collected by E. D. Merrill in 1897.

\section{Diderma globosum Pers.}

Not reported in print as occurring in the state but represented by a specimen collected by $\mathrm{R}$. Thaxter in 1902 and deposited in FH. 
Diderma hemisphaericum (Bull.) Hornem.

First reported by Harvey (1896) as Condrioderma michelii Rostaf., based on a specimen collected by G. Rex.

Diderma radiatum (L.) Morgan

First reported by Harvey (1897), based on specimens collected by F. L. Harvey and E. D. Merrill.

Diderma saundersii (Berk. \& Broome ex Massee) E. Sheld.

Not reported in print as occurring in the state but represented by a specimen collected by V. Zoll in 2012 and deposited in UARK.

Diderma sauteri (Rostaf.) E. Sheld.

First reported by Rex (1891) as Condrioderma aculeatum Rex.

Diderma simplex (J. Schröt.) E. Sheld.

Not reported in print as occurring in the state but represented by a specimen collected by M.

L. Farr in 1971 and deposited in BPI.

Diderma spumarioides (Fr.) Fr.

First reported by Harvey (1897), based on a specimen collected by E. D. Merrill in 1896.

Diderma testaceum (Schrad.) Pers.

First reported by Harvey (1896) as Condrioderma testaceum (Schrad.) Rostaf., based on a specimen collected by G. Rex, and also reported by Harvey (1899) as Chondrioderma testaceum (Rostaf.) Versuch., based on a specimen collected by E. D. Merrill in 1897.

Didymium clavus (Alb. \& Schwein.) Rabenh.

First reported by Harvey (1896), based on a specimen collected by G. Rex, and also listed by Zoll and Stephenson (2013).

Didymium crustaceum Fr.

Not reported in print as occurring in the state but represented by a specimen collected by E.

H. Walker in 1973 and deposited in BPI.

Didymium difforme (Pers.) Gray

First reported by Zoll and Stephenson (2013).

Didymium dubium Rostaf.

Not reported in print as occurring in the state but represented by a specimen collected by $\mathrm{V}$. Zoll in 2008 and deposited in UARK.

Didymium eximium Peck

First reported by Harvey (1896).

Didymium iridis (Ditmar) Fr.

First reported by Harvey (1896) as D. xanthopus Fr., based on a specimen collected by the Rev. J. Blake, and also by Harvey (1896) as D. proximum Berk. \& M.A. Curtis and based on a specimen collected by F. L. Harvey. The most recent report was by Zoll and Stephenson (2013).

Didymium melanospermum (Pers.) T. Macbr.

First reported by Harvey (1896) as D. farinaceum Schrad., based on specimens collected by F. 
L. Harvey and G. Rex, and also reported by Harvey (1897) as D. lobatum Nees, based on a specimen collected in 1896. The most recent report was by Zoll and Stephenson (2013).

Didymium minus (Lister) Morgan

First reported by Zoll and Stephenson (2013).

Didymium nigripes (Link) Fr.

First reported by Cooke (1877) as D. microcarpon Fr., based on a specimen collected by the Rev. E. C. Bolles. The species was also listed by Harvey (1896), based on specimens collected by C. B. Fuller, the Rev. J. Blake and G. Rex. The most recent report was by Zoll and Stephenson (2013).

\section{Didymium serpula Fr.}

Not reported in print as occurring in the state but represented by a specimen collected by G. W. Martin in 1940 and deposited in BPI.

Didymium squamulosum (Alb. \& Schwein.) Fr. \& Palmquist

First reported by Harvey (1896) as D. effusum Link., based on a specimen collected by G. Rex, and also listed by Zoll and Stephenson (2013).

Echinostelium minutum deBary

First reported by Zoll and Stephenson (2103).

Elaeomyxa cerifera (G. Lister) Hagelst.

First reported by Zoll and Stephenson (2013).

Enerthenema papillatum (Pers.) Rostaf.

First reported by Zoll and Stephenson (2103).

Fuligo laevis Pers.

First reported by Harvey (1899).

Fuligo muscorum Alb. \& Schwein.

First reported by Harvey (1897), based on a specimen collected by W. G. Farlow.

Fuligo septica (L.) F.H. Wigg.

First reported by Harvey (1896), based on specimens collected by F. L. Harvey and G. Rex, and also listed by Harvey (1897) as F candida Pers., based on a specimen collected by F. L. Harvey in 1895, and as F. rufa Pers. by Harvey (1899), based on a specimen collected by E. D. Merrill in 1897. The most recent report was by Zoll and Stephenson (2013).

Hemitrichia abietina (Wigand) G. Lister

First reported by Harvey (1896) as Trichia nana Mass. (collector unknown) and also as Hemiarcyria wigandii Rostaf., based on a specimen collected by F. L. Harvey.

Hemitrichia calyculata (Speg.) M.L. Farr

First reported by Harvey (1896) as Hemiarcyria plumosa Morgan, and also listed by Zoll and Stephenson (2013).

Hemitrichia clavata (Pers.) Rostaf.

First reported by Harvey (1896) as Hemiarcyria clavata [Pers.] Rostaf., based on specimens 
collected by G. Rex and F. L. Harvey, and also listed by Ricker (1902), based on a specimen collected in 1898.

Hemitrichia leiocarpa (Cooke) Lister

First collected in Maine by the Rev. E. C. Bolles and described as a species new to science (Hemiarcyria leiocarpa) by Cooke (1877).

Hemitrichia serpula (Scop.) Rostaf. ex Lister

First reported by Harvey (1896) as Hemiarcyria serpula (Scop.) Rostaf., based on a specimen collected by G. Rex.

Lamproderma arcyrioides (Sommerf.) Rostaf.

First reported by Harvey (1896) as L. violaceum Rostaf., based on a specimen collected by F. L. Harvey, and as L. arcyrioides, based on a specimen collected by G. Rex.

\section{Lamproderma columbinum (Pers.) Rostaf.}

First reported by Harvey (1896), based on a specimen collected by F. L. Harvey in 1894, and as L. physarioides Rostaf., based on specimens collected by G. Rex and F. L. Harvey in 1895. Harvey (1899) also reported the species as Physarum columbinum var. obovatum Alb. \& Schwein.

Lamproderma scintillans (Berk. \& Broome) Morgan

First reported by Harvey (1897), based on a specimen collected by E. D. Merrill in 1896.

Leocarpus fragilis (Dicks.) Rostaf.

First reported by Harvey (1896), based on specimens collected by C. B. Fuller, G. Rex and F.

L. Harvey, and also listed by Zoll and Stephenson (2013).

Lepidoderma tigrinum (Schrad.) Rostaf.

First reported by Harvey (1897).

\section{Licea biforis Morgan}

First reported by Zoll and Stephenson (2013).

\section{Licea eleanorae Ing}

Not reported in print as occurring in the state but represented by a specimen collected by V. Zoll in 2012 and deposited in UARK.

\section{Licea minima Fr.}

First reported by Harvey (1896), based on a specimen collected by the Rev. J. Blake, and also listed by Harvey (1897) and again by Zoll and Stephenson (2013).

\section{Licea operculata (Wingate) G.W. Martin}

First collected in both Maine and Pennsylvania and described as Orcadella operculata Wing. by Wingate (1889). The most recent report was by Zoll and Stephenson (2013).

\section{Licea pusilla Schrad.}

Not reported in print as occurring in the state but represented by a specimen collected by V. Zoll in 2012 and deposited in UARK.

\section{Licea cf. variabilis Schrad.}

First reported by Zoll and Stephenson (2013). 


\section{Lindbladia tubulina Fr.}

First reported by Harvey (1896) as Licea spermoides Berk. \& M.A. Curtis and collected by the Rev. J. Blake and also reported by Harvey (1899) as Lindbladia effusa var. simplex Rex, based on specimens collected by F. L. Harvey and E. D. Merrill in 1897.

Lycogala epidendrum (L.) Fr.

First reported by Harvey (1896) as L. miniatum Pers. and based on specimens collected by F. L. Harvey, the Rev. J. Blake and G. Rex. Ricker (1902) indicated that Blake's specimen had been collected in 1853. If so, this is possibly the earliest record of a myxomycete from the state. More recently, L. epidendrum was listed by Zoll and Stephenson (2013).

Lycogala flavofuscum (Ehrenb.) Rostaf.

First reported by Harvey (1897), based on a specimen collected by K. Furbish in 1896, and also listed by Harvey (1899) as L. repletum Morgan, based on a specimen collected in 1898 .

Macbrideola cornea (G. Lister \& Cran) Alexop.

Not reported in print as occurring in the state but represented by a specimen collected by $\mathrm{V}$. Zoll in 2008 and deposited in UARK.

Metatrichia floriformis (Schwein.) Nann.-Bremek.

First reported by Zoll and Stephenson (2013).

Metatrichia vesparia (Batsch) Nann.-Bremek. ex G.W. Martin \& Alexop.

First reported by Harvey (1896) as Hemiarcyria (Hemitrichia) rubiformis (Pers.) Rostaf., based on specimens collected by the Rev. J. Blake, G. Rex, and F. L. Harvey. The species was also reported by Harvey (1897) as Hemiarcyria rubiformis Pers., based on a specimen collected by E. D. Merrill. The most recent report was by Zoll and Stephenson (2013).

Mucilago crustacea F.H. Wigg.

First reported by Harvey (1897) as Spumaria alba Bull., based on specimens collected by F. L. Harvey in 1895 and by E. D. Merrill in 1896, and also reported by Ricker (1902), based on a specimen collected by F. L. Harvey in 1899.

Oligonema flavidum (Peck) Peck

Not reported in print as occurring in the state but represented by a specimen collected by R.

Thaxter in York County and deposited in FH.

Oligonema fulvum Morgan

Not reported in print as occurring in the state but represented by a specimen collected by $\mathrm{R}$.

Thaxter in York County and deposited in BPI.

Oligonema schweinitzii (Berk.) G. W. Martin

First reported by Harvey (1896) as O. nitens Rostaf.

Paradiachea rispaudii (Hagelst.) Hertel ex H. Neubert, Nowotny \& K. Baumann

First reported by Zoll and Stephenson (2013).

Paradiacheopsis rigida (Brândza) Nann.-Bremek.

Not reported in print as occurring in the state but represented by a specimen collected by $\mathrm{V}$. Zoll in 2012 and deposited in UARK. 
Paradiacheopsis cf. solitaria (Nann.-Bremek.) Nann.-Bremek.

First reported by Zoll and Stephenson (2013).

Perichaena chrysosperma (Curr.) Lister

First reported by Harvey (1896) as Cornuvia wrightii Rostaf., based on a specimen collected by G. Rex, and also listed by Zoll and Stephenson (2013).

Perichaena corticalis (Batsch) Rostaf.

First reported by Harvey (1897) as $P$. marginata Schwein., based on a specimen collected in 1896 by E. D. Merrill, and also reported by Ricker (1902) as P. marginata, based on a specimen collected by F. L. Harvey.

Perichaena depressa Lib.

First reported by Harvey (1896), based on a specimen collected by G. Rex, and also listed by Zoll and Stephenson (2013).

Perichaena vermicularis (Schwein.) Rostaf.

First reported by Zoll and Stephenson (2013).

Physarum album (Bull.) Chevall.

First reported by Harvey (1896) as P. nutans Pers. and based on specimens collected by C. B. Fuller, the Rev. J. Blake, G. Rex and F. L. Harvey, and also listed by Harvey (1899) as Physarum leucophaeum var. violascens Rostaf., based on a specimen collected in 1896, and as P. albipes Link, based on a specimen collected in 1897. The most recent report was by Zoll and Stephenson (2013).

Physarum auriscalpium Cooke

Not reported in print as occurring in the state but represented by a specimen collected by R. Thaxter in 1923 and deposited in FH.

Physarum bivalve Pers.

First reported by Harvey (1896) as P. sinuosum (Bull.) Rostaf., based on a specimen collected by G. Rex, and also reported by Harvey (1899) as $P$. sinuosum, based on a specimen collected by E. D. Merrill in 1897.

Physarum braunianum de Bary

First reported by Zoll and Stephenson (2013).

Physarum cinereum (Batsch) Pers.

First reported by Harvey (1896), based on a specimen collected by G. Rex, and also listed by Zoll and Stephenson (2013).

Physarum citrinum Schumach.

First reported by Harvey (1897) as Cytidium rufipes Alb. \& Schwein., based on specimens collected in 1896 by E. D. Merrill and F. L. Harvey, and also listed by Harvey (1899).

Physarum compressum Alb. \& Schwein.

First reported by Harvey (1897) as P. connexum Link.

Physarum confertum T. Macbr.

First reported by Zoll and Stephenson (2013). 
Physarum contextum (Pers.) Pers.

First reported by Harvey (1896), based on specimens collected by F. L. Harvey and G. Rex.

Physarum crateriforme Petch

Not reported in print as occurring in the state but represented by a specimen collected by $\mathrm{V}$. Zoll in 2013 and deposited in UARK.

Physarum decipiens M.A. Curtis

Not reported in print as occurring in the state but represented by a specimen collected by C. L. Shear in 1917 and deposited in BPI.

Physarum diderma Rostaf.

First reported by Harvey (1897).

Physarum didermoides (Pers.) Rostaf.

First reported by Harvey (1896) as Didymium congestum Berk. \& Broome, based on a specimen collected by C. B. Fuller.

Physarum flavicomum Berk.

First reported by Harvey (1896) as P. cupripes Berk. \& Ravenel.

Physarum flavidum (Peck) Peck

First reported by Harvey (1896) as P. citrinellum Peck.

Physarum globuliferum (Bull.) Pers.

First reported by Harvey (1896) as P. petersi var. farlowii Rostaf. and also listed by Harvey (1897) as Cytidium globuliferum Bull., based on specimens collected by F. L. Harvey and E. D. Merrill in 1896. More recently, the species was reported from the state by Zoll and Stephenson (2013).

Physarum gyrosum Rostaf.

Not reported in print as occurring in the state but represented by specimens collected by C. B. Stifler in 1938 and deposited in both UARK and FLAS.

Physarum lateritium (Berk. \& Ravenel) Morgan

Not reported in print as occurring in the state but represented by a specimen collected by V. Zoll in 2014 and deposited in UARK.

Physarum leucophaeum Fr. \& Palmquist

First reported by Harvey (1896), based on specimens collected by F. L. Harvey and G. Rex, and also reported by Harvey $(1897,1899)$ as $P$. imitans Racib. The most recent report was by Zoll and Stephenson (2013).

\section{Physarum leucopus Link}

First reported by Harvey (1899), based on a specimen collected in 1897 by E. D. Merrill.

\section{Physarum luteolum Peck}

Not reported in print as occurring in the state but represented by a specimen collected in Maine by G. A. Rex and deposited in BPI. 
Physarum notabile T. Macbr.

First reported by Harvey (1897) as $P$. connexum Link and based on a specimen collected in 1896.

Physarum nudum T. Macbr.

Not reported in print as occurring in the state but represented by a specimen collected in Maine by R. Thaxter and deposited in BPI.

Physarum oblatum T. Macbr.

First reported by Harvey (1897) as $P$. ornatum Peck and collected in 1896.

\section{Physarum penetrale Rex}

First reported by Rex (1891).

Physarum polycephalum Schwein.

First reported by Ricker (1902) as P. obrusseum (Berk. \& M.A. Curtis) Rostaf. and based on a specimen collected by F. L. Harvey in 1887.

\section{Physarum psittacinum Ditmar}

First reported by Harvey (1899), based on a specimen collected by E. D. Merrill in 1897, and also listed by Zoll and Stephenson (2013).

\section{Physarum pulcherripes Peck}

Not reported in print as occurring in the state but represented by a specimen deposited in BPI (collector unknown).

Physarum stellatum (Massee) G.W. Martin

First reported by Harvey (1899) as P. compactum Lister.

\section{Physarum tenerum Rex}

First reported by Harvey (1899).

\section{Physarum vernum Sommerf.} 1896.

First reported by Harvey (1897) as Badhamia verna Rostaf., based on a specimen collected in

\section{Physarum virescens Ditmar}

First reported by Harvey (1896) as P. ditmari Rostaf., based on a specimen collected by G. Rex. The most recent report was by Zoll and Stephenson (2013).

Physarum viride (Bull.) Pers.

First reported by Harvey (1896), based on a specimen collected by G. Rex, and also listed by Harvey (1899) as $P$. viride var. aurantium (Bull.) Lister. The most recent report was by Zoll and Stephenson (2013).

\section{Reticularia lycoperdon Bull.}

First reported by Harvey (1897) as R. umbrina Fr., based on specimens collected by F. L. Harvey and E. D. Merrill.

\section{Reticularia splendens Morgan}

First reported by Harvey (1896) as Enteridium rozeannum Wing. and also listed by Harvey (1897), based on specimens collected by F. L. Harvey and E. D. Merrill. The most recent report 
was by Zoll and Stephenson (2013).

Stemonaria irregularis (Rex) Nann.-Bremek., R. Sharma \& Y. Yamam.

First reported by Harvey (1896) as Comatricha crypta (Schwein.) T. Macbr. and based on a specimen collected by F. L. Harvey in 1895 and as C. irregularis Rex based on a specimen collected by F. L. Harvey.

Stemonitis axifera (Bull.) T. Macbr.

First reported by Harvey (1896) as S. ferruginea Ehrenb. and based on specimens collected by G. Rex and F. L. Harvey, and also listed by Harvey (1899) as S. microspora Lister and based on a specimen collected by E. D. Merrill. The most recent report was by Zoll and Stephenson (2013).

Stemonitis flavogenita E. Jahn

Not reported in print as occurring in the state but represented by a specimen collected by K. E. Winsett and deposited in UARK.

\section{Stemonitis fusca Roth}

First reported by Harvey (1896) based on specimens collected by the Rev. J. Blake, G. Rex, and F. L. Harvey, and also listed by Zoll and Stephenson (2013). Our records include several specimens that would be referred to S. fusca var. nigrescens (Rex) Torrend if this variety is recognized.

\section{Stemonitis herbatica Peck}

First reported by Harvey (1896).

Stemonitis smithii T. Macbr.

First reported by Harvey (1896), based on a specimen collected F. L. Harvey in 1895, and also listed by Zoll and Stephenson (2013).

Stemonitis splendens Rostaf.

Not reported in print as occurring in the state but represented by a specimen collected by $\mathrm{J}$. C. Parlin in 1923 and deposited in FH.

\section{Stemonitis virginiensis Rex}

First reported by Zoll and Stephenson (2013).

\section{Stemonitopsis aequalis (Peck) Y. Yamam.}

First reported by Harvey (1899) as Comatricha aequalis Peck, also listed by Ricker (1902) as

C. aequalis and based on a specimen collected by P. L. Ricker in 1896.

Stemonitopsis hyperopta (Meyl.) Nann.-Bremek.

First reported by Zoll and Stephenson (2013).

Stemonitopsis typhina (F.H.Wigg.) Nann.-Bremek.

First reported by Harvey (1896) as Comatricha typhoides Rostaf., based on specimens collected by C. B. Fuller, G. Rex and F. L. Harvey, and also listed by Zoll and Stephenson (2013).

Symphytocarpus cf. flaccidus (Lister) Ing \& Nann.-Bremek.

First reported by Zoll and Stephenson (2013).

Symphytocarpus trechisporus (Berk. ex Torrend) Nann.-Bremek.

Not reported in print as occurring in the state but represented by a specimen collected by R. 
Thaxter and deposited in BPI and also by specimens collected by R. Thaxter (in 1905 and 1919) and T. H. McBride (no date given) and deposited in TRTC.

Trichia affinis de Bary

First reported by Harvey (1896).

Trichia botrytis (J.F. Gmel.) Pers.

First reported by Harvey (1897) as T. fragilis (Sowerby) Rostaf., based on a specimen collected by E. D. Merrill in 1896, and also reported by Ricker (1902), again as T. fragilis and based on a specimen collected by P. L. Ricker in 1898. The most recent report was by Zoll and Stephenson (2013).

Trichia contorta (Ditmar) Rostaf.

First reported by Harvey (1896) as both $T$. contorta and $T$. reniformis Peck, based on different specimens, and also reported by Harvey (1896) as T. inconspicua Rostaf., based on specimens collected by G. Rex and F. L. Harvey. The most recent report was by Zoll and Stephenson (2013).

Trichia decipiens (Pers.) T. Macbr.

First reported by Harvey (1896) as T. fallax Pers., based on specimens collected by F. L. Harvey and G. Rex. The most recent report was by Zoll and Stephenson (2013).

Trichia favoginea (Batsch) Pers.

First reported by Cooke (1877) as T. chrysosperma Bull., based on a specimen collected by E. C. Bolles, and also as T. abrupta Cooke, based on a specimen collected by C. B. Fuller. Later, the species was reported by Harvey (1896) as both T. chrysosperma (Bull.) DC and T. jackii Rostaf. The most recent report was by Zoll and Stephenson (2013).

\section{Trichia scabra Rostaf.}

First reported by Cooke (1877), based on a specimen collected by C. B. Fuller, and also reported by Harvey (1896), based on specimens collected by F. L. Harvey and G. Rex in 1895.

\section{Trichia subfusca Rex}

First reported by Harvey (1896) and also listed by Zoll and Stephenson (2013).

Trichia varia (Pers. ex J.F. Gmel.) Pers.

First reported by Harvey (1896) as T. varia var. sessilis Rostaf., based on specimens collected by the Rev. J. Blake and F. L. Harvey, and as T. varia, based on specimens collected by F. L. Harvey and G. Rex.

Tubifera ferruginosa (Batsch) J.F. Gmel.

First reported by Harvey (1896) as Licea fragiformis Fr., based on a specimen collected by the Rev. J. Blake, and as Tubulina fragiformis Pers., based on specimens collected by F. L. Harvey and G. Rex. Harvey (1897) also reported the species as Licea fragiformis. The most recent report was by Zoll and Stephenson (2013).

Willkommlangea reticulata (Alb. \& Schwein.) Kuntze

Not reported in print as occurring in the state but represented by a specimen collected by V. Zoll in 2013 and deposited in UARK.

\section{Discussion}

The number of species of myxomycetes reported from or known to occur in Maine is 166, which is lower than the total (220) reported from the Great Smoky Mountains National Park by 
Stephenson and Landolt (2009). However, the latter figure is the highest known for any area of comparable size in temperate regions of the world. The total for Maine exceeds those of a number of other states, including Arkansas (Eliasson et al. 1988; Stephenson, unpublished data), Arizona (Bates \& Barber 2008) and West Virginia (Stephenson 1987), for which similar data are available. Indeed, the number of species of myxomycetes recorded from Maine is higher than the totals reported for such tropical countries as Thailand (Ko et al. 2010). As a result of the surveys carried out in the context of the All Taxa Biodiversity Inventory, the myxomycetes of the Great Smoky Mountains National Park have been subjected to an intensive sampling effect that has involved a number of individuals who are among the world's leading authorities on this group of organisms. In addition, the range of different vegetation types found in the park exceeds that of the state of Maine. These two factors almost certainly account for the appreciably higher number of species known from the Great Smoky Mountains National Park. Nevertheless, the total for Maine is high enough to indicate that the total collecting effort carried out in the state since the 1850's can be regarded as impressive, especially when the number of individuals who have contributed to this effort are considered.

The myxomycetes remain an understudied group in most regions of the world, but these organisms appear to be relatively well documented for Maine. However, there are portions of the state and certain microhabitats (e.g., soil) that have not yet been investigated in any detail. As such, we hope that the set of data presented in this paper will encourage others to continue adding to the body of information available on the myxomycetes of this state.

\section{Acknowledgments}

Appreciation is extended to Seanna Annis (University of Maine in Orono), Laurence Leonard and Ian Medeiros (Curatorial Assistant at the College of the Atlantic) for their assistance in obtaining some of the data reported herein.

\section{References}

Bates ST, Barber A. 2008 - A preliminary checklist of Arizona slime molds. Canotia 4, 8-19.

Cooke MC. 1877 - The Myxomycetes of the United States. Annals of the Lyceum of Natural History of New York 11, 378-409.

Eliasson UH, Keller HW, Hutchison JA. 1988 - Myxomycetes from Arkansas. Mycotaxon 32, 375-398.

Gilbert HC, Martin GW 1933 - Myxomycetes found on the bark of living trees. University of Iowa Studies in Natural History 15, 3-8.

Hagelstein R. 1944 - Mycetozoa of North America. Published by the author, Mineola, New York.

Harvey FL. 1896 - Contribution to the Myxogasters of Maine. Bulletin of the Torrey Botanical Club 23, 307-314.

Harvey FL. 1897 - Contribution to the Myxogasters of Maine.--II. Bulletin of the Torrey Botanical Club 24, 65-71.

Harvey FL. 1899 - Contribution to the Myxogasters of Maine.-III. Bulletin of the Torrey Botanical Club 26, 320-324.

Ko KTW, Hanh TTM, Stephenson SL, Mitchell DW, Rojas C, Hyde KD, Lumyong S, Bahkali AH. 2010 - Myxomycetes of Thailand. Sydowia 62, 243-260.

Lado C. 2005-2015. An online nomenclatural information system of Eumycetozoa. http://www.nomen.eumycetozoa.com (accessed on 10 April 2015).

Macbride TH. 1899 - The North American Slime-Moulds. Macmillan Company, New York.

McCaskill GL, McWilliams WH; Barnett CJ, Butler BJ, Hatfield MA, Kurtz CM, Morin RS, Moser WK, Perry CH, Woodall CW. 2011 - Maine's forests 2008. Resource Bulletin NRS-48. Newtown Square, PA: United States Department of Agriculture, Forest Service, Northern Research Station. 62 p. 
McWilliams WH, Butler BJ, Caldwell LE, Griffith DM, Hoppus ML, Laustsen KM, Lister AJ, Lister TW, Metzler JW, Morin RS, Sader SA, Stewart LB, Steinman JR, Westfall JA, Williams DA, Whitman A, Woodall CW. 2003 - The forests of Maine. Resource Bulletin NE-164. Newtown Square, PA: United States Department of Agriculture, Forest Service, Northeastern Research Station, Newton Square, Pennsylvania. 188 p.

Martin GW, Alexopoulos CJ. 1969 - The Myxomycetes. University of Iowa Press, Iowa City.

Rex GA. 1891 - New American Myxomycetes. Proceedings of the Academy of Natural Sciences of Philadelphia 43, 389-398.

Ricker PL. 1902 - A preliminary list of Maine fungi. University of Maine Studies 3, 9-18.

Rojas C, Stephenson SL. 2013 - Effect of forest disturbance on myxomycete assemblages in the southwestern Peruvian Amazon. Fungal Diversity 59, 45-53.

Rollins AW, Stephenson SL. 2013 - Myxomycetes associated with grasslands of the western central United States. Fungal Diversity 59, 147-158.

Sprague CJ. 1856-1859 - Contributions to New England Mycology. Proceedings of the Boston Society of Natural History 6, 315-321.

Stephenson SL. 1987 - New records of myxomycetes from West Virginia. IV. Castanea 52, 142144.

Stephenson SL. 1989 - Distribution and ecology of myxomycetes in temperate forests. II. Patterns of occurrence on bark surface of living trees, leaf litter, and dung. Mycologia 81, 608-621.

Stephenson SL, Landolt JC. 2009 - Mycetozoans of the Great Smoky Mountains National Park: an All Taxa Biodiversity Inventory project. Southeastern Naturalist 8, 317-324.

Wingate H. 1889 - Orcadella operculata Wing., a new Myxomycete. Proceedings of the Academy of Natural Sciences of Philadelphia 41, 280-281.

Wrigley de Basanta D, Lado C, Estrada-Torres A, Stephenson SL. 2013 - Biodiversity studies of myxomycetes in Madagascar. Fungal Diversity 59, 55-83.

Zoll V, Stephenson SL. 2013 - Myxomycete records from Eagle Hill in Maine. Mycosphere 4, 532-537. 